\title{
Integrated Fuzzy AHP-TOPSIS Method to Analyze Green Management Practice in Hospitality Industry in the Sultanate of Oman
}

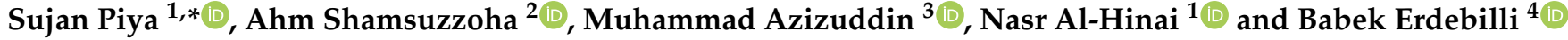 \\ 1 Department of Mechanical and Industrial Engineering, College of Engineering, Sultan Qaboos University, \\ P.O. Box 50, Muscat 123, Oman; nhinai@squ.edu.om \\ 2 Digital Economy Research Platform, School of Technology and Innovations, University of Vaasa, P.O. Box 700, \\ FI-65101 Vaasa, Finland; ahm.shamsuzzoha@uwasa.fi \\ 3 School of Strategy and Leadership, Faculty of Business and Law, Coventry University, Coventry CV1 5FB, UK; \\ ad7655@coventry.ac.uk \\ $4 \quad$ Industrial Engineering Department, Ankara Yıldırım Beyazıt University, Ankara 06010, Turkey; \\ berdebilli@ybu.edu.tr \\ * Correspondence: sujan@squ.edu.om
}

Citation: Piya, S.; Shamsuzzoha, A.; Azizuddin, M.; Al-Hinai, N.; Erdebilli, B. Integrated Fuzzy AHP-TOPSIS Method to Analyze Green Management Practice in Hospitality Industry in the Sultanate of Oman. Sustainability 2022, 14, 1118 https://doi.org/10.3390/su14031118

Academic Editor: Luigi Aldieri

Received: 22 November 2021

Accepted: 20 December 2021

Published: 19 January 2022

Publisher's Note: MDPI stays neutral with regard to jurisdictional claims in published maps and institutional affiliations.

Copyright: (C) 2022 by the authors. Licensee MDPI, Basel, Switzerland. This article is an open access article distributed under the terms and conditions of the Creative Commons Attribution (CC BY) license (https:// creativecommons.org/licenses/by/ $4.0 /)$.

\begin{abstract}
Climate change is the most serious threat that the modern world has ever faced. This has led to increasing attention from the government, industries, researchers, and practitioners on the theme of green practice. Due to the heightened awareness of climate change, the hospitality industry is under pressure to implement green practices and reduce the environmental impact of their operation. The research aims at understanding the indicators that define green practice in the hospitality industry and then developing a model that can be used to measure the green score. The research identifies twenty-six indicators of green practice in the hotel industry. These indicators were clustered into six different criteria. Based on the identified indicators and criteria, an integrated fuzzy AHP-TOPSIS method is proposed to calculate the green score. The fuzzy AHP method is used to calculate the weight of the criteria and indicators, while the fuzzy TOPSIS method is used to calculate the green score and rank hotels. The fuzzy AHP result shows that the criterion "Recycling and Reuse" has the highest weight among the identified criteria, while "Green Training and Incentives" has the lowest weight. The application of the proposed method is demonstrated by using a case study of hotels situated in the Sultanate of Oman. The result shows that the 4-star and 5-star hotels in the Sultanate have green scores between 0.56 and 0.641 out of 1.0 at a $95 \%$ confidence interval. The results further show that having a high star ranking hotel does not necessarily mean that the hotel is better in terms of green practice. The developed model helps the hotel industry to understand the indicator and criteria, as identified in this research work, they need to improve in order to improve their overall green management practice.
\end{abstract}

Keywords: green practice; hospitality industry; fuzzy method; analytical hierarchy process; TOPSIS; green score; Oman

\section{Introduction}

Due to the increasing awareness of the negative impact the hospitality industry has on the environment, organizations are under pressure to minimize the waste they create and its impact on the environment. Moreover, the firms want their performance and product to be more environmentally friendly as customers nowadays are more aware of the impact their behavior has on the environment and society [1]. From this perspective, the firms need to integrate green initiatives and programs into their operations. This has led to the concept of green management practices and has become an integral part of many industrial sectors. The word "green" emphasizes being energy efficient, conserving available resources, and implementing green practices in managing the system. Green 
management practice includes activities related to managing material and information flows inside and outside the organization to distribute the product or service and deliver it to the end-user while considering the environmental and economic aspects. Such practice can be applied in any industrial sector such as academic institutions, the manufacturing industry, and the service industry. Some of the green practices that could be applied in these industries are minimizing waste in terms of low consumption of energy, water-saving, recycling, minimizing transportation emissions, etc. Research has shown that such practices lead to cost reduction thus meeting stakeholders' needs while minimizing the negative impact the industry has on the environment [2-4]. Implementation of green practice and philosophy now has become essential as stakeholders and scholars have forced the firms to alter their process and strategize their operations taking into account the environmental, social, and economic impact [5].

The tourism industry is one of the fastest-growing industries and is an increasingly important source of income, employment, and wealth in many countries [6]. The hospitality sector or hotel is one of the major pillars of the tourism supply chain. The industry continuously develops in terms of infrastructure and services provided to increase the satisfaction of the customer. This industry contributes significantly to employment and economic development [7]. However, on the other hand, research has shown that the hospitality industry is one of the major contributors to climate change as it emits a significant proportion of carbon dioxide, generates waste, and consumes significant amounts of water and energy [8,9]. Therefore, due to government pressure and customers' green awareness, the hospitality industry has started implementing green practices as part of its competitive strategy [10,11]. Research by Kim et al. [12] has found that there is a positive relationship between green practice by the hospitality industry and the satisfaction level of the customer. Much research has noted that awareness for green products and services is growing amongst hotel guests and customers nowadays are willing to pay more for environmental products. Moreover, cost-saving is another important motivation for green practices in the hospitality industry [13]. This demands the industries to analyze the environmental impact and the green practice across their operations, and assess their green performance.

Much research has been carried out in the pursuit of understanding the effect of green practice and green innovation in hospitality industries [2,3]. However, research is needed to understand the level of green practices implemented by hotels [4]. This can be done by first identifying the criteria and indicators that can be used to measure the level of green practices. Therefore, to bridge the research gap, this research aims at addressing the following research questions.

RQ 1: Identify the criteria and indicators that define the implementation of green practice in the hotel industry;

RQ 2: Develop a quantitative tool to understand the importance of one criterion and indicator over others;

RQ 3: Formulate a mathematic model to calculate the green score based on which hotel can be compared for their green practice.

The remaining part of the paper is organized as follows. Section 2 summarizes the relevant literature in the field and highlights the research gaps. Section 3 discusses in detail the methodology followed in this research work. A case study is enumerated to show the application of the proposed method in Section 4. Finally, the research is concluded along with possible future research directions in Section 5.

\section{Literature Review}

The devastating effects of organizational practice on the environment have forced firms to adopt environmentally sustainable practices and put focus on their overall environmental performance [14] and the hospitality sector is no exception. The hospitality sector became a more important issue to investigate due to its functional nature, characteristics, and services, which all consume a high amount of energy, water, and use of non-durable products. The major environmental impacts take place on the site planning and facility management; 
excessive consumption of non-durable goods, energy, and water, and emission into the air, water, and soil [15]. Bohdanowicz [16] mentioned that hotels release between 160 and $200 \mathrm{~kg} \mathrm{co}{ }^{2}$ per square meter of rooms. In addition, Pacific Gas and Electric's Food Service Technology Center (FSTC) revealed that hotels are the world's largest energy users [17]. The usage of the energy in the hotels is five times energy per unit square foot when compared to any other commercial building, and they produce 490 tons of carbon dioxide per year per restaurant [18].

Over the last decade, green and renewable energy has played a major role in the world, including the hospitality sector [19]. Renewable energy is gathered from renewable resources including sunlight, wind, rain, tides, waves, and geothermal heat. In the framework of a low-carbon world economy, green and renewable energy production is an important way to conserve electricity and reduce emissions. Renewable energy sources are now at the forefront of sustainable hotel design, as it does not only demonstrate that you are clearly mindful of saving the environment, but the running costs are also minimized. Green buildings use on average 26\% less energy, emit 33\% less greenhouse emission, use $30 \%$ less indoor water, and send $50-75 \%$ less solid waste to landfills and incinerators.

The importance of innovation in the hospitality sector is to arise a competitive environment and help the firm in long-term success specifically when the innovation recalls environmental sustainability. Whatever the employees create from new products or services, new plans, new developing strategies are considered innovations, which add competitive advantages to the organization [20]. Studies show that the ability to create product or service lead to cost reduction through green practices [21]. Moreover, most consumers tend to pay more for green products to feel satisfied with saving the environment; eventually, this will end with benefits to the organizational performance [22]. Furthermore, hospitality industries tend to adopt green innovation to achieve environmental performance [23]. This will enhance the organization's reputation, improve productivity, reduce operational costs, and reduce the emission of gases in hotels [3].

The above observations have encouraged academicians, researchers, and development practitioners to study and characterize the green policies of hotels and their waste management programs. However, many researchers have investigated waste within the hotels and different areas but without extending the scope to the whole supply chain. It is clear that most of the studies focus on physical wastes. For example, ref. [24] studied the issue of waste management by conducting a survey of selected hotels in Turkey. They grouped different kinds of wastes produced by the hotels and they found that the greatest amount of hotel waste is in the form of paper and food waste. Al-Aomar and Hussain [4] pointed out that there is a shortage of academic research on conceptual and theoretical approaches that can be utilized by the hospitality industry to explore and assess the extent of adopting green practices within the supply chains. This paper attempts to fill the research gap that exists in this area.

In this paper, at first the criteria and indicators which define the green management practices in the hotel supply chain are identified through an extensive literature survey. Thereafter, integrated fuzzy-AHP-TOPIS is applied in a case study. Fuzzy AHP is used to evaluate and rank the identified green criteria and indicators. On the other hand, fuzzy TOPSIS is used to rank the hotels under study. To the best of our knowledge, this is one of the first research to introduce the integrated fuzzy AHP-TOPSIS method to analyze the green management practice in the hospitality industry and rank hotels based on such practice.

\section{Proposed Methodology}

As shown in Figure 1, the methodology starts with the identification of criteria that define green management practice (GMP) and indicators that delineate the criteria in terms of its implementation. The weight of the criteria and indicators are then calculated by using the fuzzy AHP method. Next, the necessary data on the alternative to be ranked are collected based on the questionnaire survey, the details of which will be discussed in 
Section 4. Finally, the fuzzy TOPSIS method is used to calculate the GMP score of each alternative and then rank them. It should be noted that while using the fuzzy TOPSIS method, the weight obtained from the fuzzy AHP method is used. The next section will discuss the GMP criteria and indicators, the fuzzy AHP method, and fuzzy TOPSIS in detail.

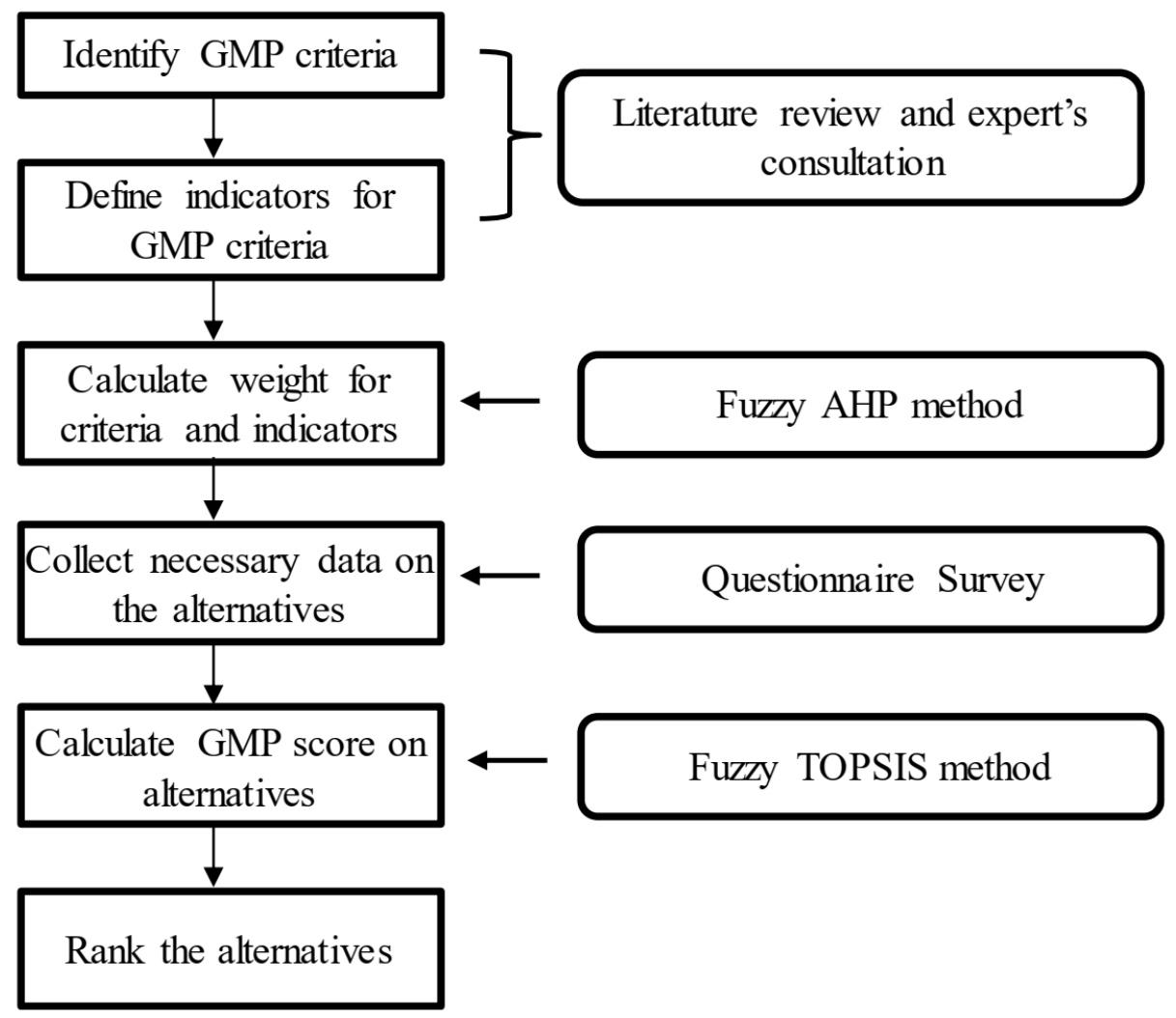

Figure 1. Methodological steps followed.

\subsection{GMP Criteria and Indicators}

An extensive literature survey was conducted in order to identify the criteria and indicators that define the GMP in the hotel industry. For this literature survey, several keywords such as "Green practice", "Sustainable management criteria", "Hotel supply chain", "Hospitality industry and green practice", "Green hotels", etc., were used. Various available databases such as Science Direct, Scopus, Emerald, Springer, Google Scholar, and ISI Web of Science were used during the literature survey. The identified criteria and indicators as collected from the literature review were validated through six experts' opinions. Out of six experts, two of them were academicians who have wider experiences in both teaching and research in the area of SC management, and the rest were chosen from the hotel industries with experiences of more than 10 years and currently working as a manager/senior manager. All the identified and consolidated criteria and the indicators are discussed in the following subsections.

\subsubsection{Recycling and Reuse}

Today's era of practicing green economy and green strategies, in the form of recycling and reusing of wastes, can support plenty of opportunities to hotel industry [25]. The most efficient way of reducing waste is to minimize the waste generated during operation, develop waste disposal partnerships, and create sound waste disposal methods. Reduction and reuse of the wastes are among the most efficient ways of preserving natural resources, protecting the atmosphere, and saving costs [26]. Within the corporate world, sustainabilitybased activities save companies quite a lot of money. In order to reduce resource utilization, 
the companies use the three R's (Reduce, Reuse, and Recycle) principle. However, this reducing, reusing, and recycling principle has some downsides but beneficial with respect to environmental concerns and to waste reduction and needs a trade-off [22,27].

\subsubsection{Transportation}

Transportation is considered one of the important elements that have a fundamental role in designing the supply chain [28]. There are critical impacts associated with transportation such as global warming, environmental deterioration, health effects (physical, emotional, mental, spiritual), and greenhouse gas emissions [23]. Green transportation is expected in order to maintain environmental sustainability. This requires a committed initiative from the public with respect to knowledge sharing and involvement in the vehicle design, development, and management using renewable energy sources, such as wind, solar, biofuels, and hydropower [29]. In the hospitality industry, transportation is an integral part of the supply chain, which is necessary for the movement of goods, as well as guests.

\subsubsection{Energy Consumption}

Energy consumption in hotels differs considerably between hotel types, sizes, classes/ categories, number of rooms, customers profiles (guests visiting for business/holidays), locations (rural/remote or urban), environmental zones, services/activities types, and facilities available to guests. Major energy savings can be achieved through a commonsense approach that requires neither advanced expertise nor overinvestment [30,31].

\subsubsection{Water Efficiency and Conservation}

Due to the continuous growth of the global population, water has been depleting in an aggressive way in order to satisfy the supply and demand in the forms of providing fresh water to the customers for everyday uses such as drinking, showering, food service, etc. [32]. It is important to spread environmental awareness among customers in order to contribute to the use of water-friendly products that contribute to the green supply chain practices. In addition, using smart technologies and techniques like sensors, controlled valves, and pressure pipes can be used to control and reduce the amount of water used which also contributes to the financial aspects of managing hotels [33].

\subsubsection{Commitment to Environmental Practices}

The environmental commitment defines the ways, policies, and responsibilities adopted by the hotel management authority to prevent and manage environmental issues and impacts [22]. The hotel management authorities that care about the environment and establish necessary rules and regulations to protect the natural resources may work as attractive factors for the clients and may be supported by the government and other facilities. Moreover, this will also help to create and adopt green innovation through controlling energy, water, and waste [34]. Furthermore, we can keep in mind that government regulations can enhance green performance within the hotel industry that also fosters environmental sustainability [35].

\subsubsection{Green Training and Incentives}

Green training and incentives can be ensured within the hotel management authorities through establishing sustainable collaborations and recognition. This collaboration can be fostered through building commitment and trust within the participants such as top managers, HR, and employees within an organization [5]. The top managers set up the criteria for tracking the progress of the green practices and training across an organization including partnerships, knowledge sharing, and supply chain management. The HR department usually provides training for the employees of an organization to deal with issues related to the environment [34]. HR activities promote the implementation and maintenance of an environmental management system, thus helping an organization to achieve better environmental performance. Moreover, practices in the HR department can 
have a greater environmental and organizational impact if applied jointly [36,37]. It should be noted that organizations that continue to follow green sustainable business practices can strive for a greener organizational culture that contributes to improved efficiencies, increased sales, reduced costs, and a healthier environment for employee engagement [36]. Some of the studies also indicated that quality management (QM) activities such as ISO 9001 and other total quality management (TQM) certification programs can promote or accelerate the adoption of environmental practices and effectiveness in organizations.

All the above-identified criteria and indicators related to these criteria for green management practices in the hotel industry are accumulated and highlighted in Table 1 below.

Table 1. Criteria and indicators of green management practice in the hotel industry.

\begin{tabular}{|c|c|c|}
\hline Ref. & Criteria & Indicator \\
\hline$[18,22,25-27]$ & C1: Recycling and Reuse & $\begin{array}{l}\text { SC11: Design for recycling water and minimizing waste } \\
\text { throughout the hotel. } \\
\text { SC12: Use of environmentally friendly raw materials like } \\
\text { returnable, reused, and recyclable packaging. } \\
\text { SC13: Use electronic files rather than paper ones. }\end{array}$ \\
\hline$[12,23,29,38]$ & C2: Transportation & $\begin{array}{l}\text { SC21: Encourage environmentally friendly transportation } \\
\text { through incentives. } \\
\text { SC22: Provide preferential car parking for alternative transport } \\
\text { modes, such as electric, hybrid, or biodiesel carpools. } \\
\text { SC23: Provide a secure location for staff to store and rent bicycles. }\end{array}$ \\
\hline$[8,19,31]$ & C3: Energy Efficiency and Conservation & $\begin{array}{l}\text { SC31: Install sensors or timers for the occupancy (motion) in low } \\
\text { traffic areas. } \\
\text { SC32: Use energy-efficient lamps, such as compact fluorescent } \\
\text { (CFL) lights. } \\
\text { SC33: Where possible, use renewable sources of energy such as } \\
\text { wind, solar, and geothermal resources. } \\
\text { SC34: Set up programmable thermostats in place. } \\
\text { SC35: Use (key-card) to activate and turn off the electricity in } \\
\text { rooms. } \\
\text { SC36: Install heat-insulated windows or use natural sunlight to } \\
\text { reduce the average energy usage. } \\
\text { SC37: Using solar panels for heating water. } \\
\text { SC38: Provide reminding cards for visitors and workers to turn } \\
\text { off the lights when they leave the room. } \\
\text { SC39: Perform periodic maintenance for electrical devices. }\end{array}$ \\
\hline$[15,32,33]$ & C4: Water Efficiency and Conservation & $\begin{array}{l}\text { SC41: Post signs for reducing water usage in toilets, restaurants, } \\
\text { and kitchen areas. } \\
\text { SC42: Check for water leakages and repairs periodically. } \\
\text { SC43 Washing machines, dryers, and dishwashers are fully filled } \\
\text { in to reduce water usage. } \\
\text { SC44: Use an automated irrigation system for gardening. } \\
\text { SC45: Conserve water by using tap sensors. }\end{array}$ \\
\hline
\end{tabular}

SC51: The hotel forms an environmental committee for green practices. $[3,6,9,24] \quad$ C5: Commitment to Environmental
Practices
SC52: Hotel staff are informed about any issues related to the environment.

SC53: The environmental efforts of the hotel are visibly communicated to the guests, the personnel, shareholders, salespeople, and the public. 
Table 1. Cont.

\begin{tabular}{ccc}
\hline Ref. & Criteria & Indicator \\
\hline C6: Green training and incentives & $\begin{array}{c}\text { SC61: Offer training to the employees on issues relating to the } \\
\text { protection of the environment. } \\
\text { SC62: Provide staff with incentives in case of submitting } \\
\text { suggestions for environmental issues. }\end{array}$ \\
$\begin{array}{c}\text { SC63: Accurate identification of waste such that an appropriate } \\
\text { control strategy can be made. }\end{array}$
\end{tabular}

\subsection{Fuzzy AHP}

The analytic hierarchy process (AHP) is one of the widely used multi-criteria decisionmaking (MCDM) approaches. AHP is used to calculate, order, rank, and assess decision choices. By pairwise comparisons between the decision criteria, the AHP approach is used to identify the weights of each criterion that affects the decision. It is a rigorous means of mathematically translating the subjective judgment of decision-makers into numerical results [39]. To deal with fuzziness in the MCDM scenario, fuzzy analytical hierarchy (FAHP) processes have found major applications in recent years [40]. Fuzzy AHP is used due to its ability to deal with an unbalanced scale of judgment and uncertainty associated with the mapping of one's judgment to a number [41]. This research uses the fuzzy AHP approach to compute the weight of the identified green criteria and indicators. In this research, the triangular fuzzy membership function is considered for the shape as it is simple to use and intuitively easy to infer and calculate by the decision-makers as compared to other shapes [42]. The graphical representation of the membership function is shown in Figure 2 .

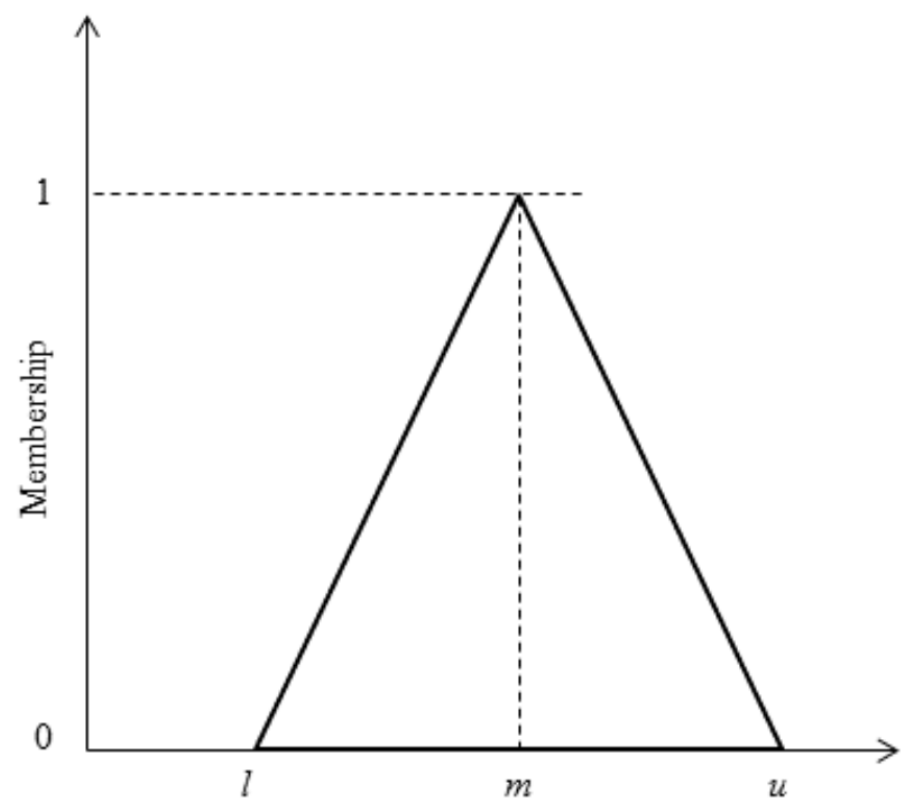

Figure 2. Triangular member function.

The following steps are followed to use the fuzzy AHP method.

\subsubsection{Perform Pairwise Comparison}

The first step is to construct a fuzzy pairwise comparison matrix. The matrix is constructed by comparing the identified criteria in terms of the importance of one criterion over others for green practice. For the comparison, expert opinion is solicited in terms of linguistic scale as defined by Saaty [43], which is as shown in Table 2. In the matrix in 
Equation (1), the element $x_{k i j}$ represents the linguistic scale obtained from an expert $(k)$ regarding the degree of preference of $i^{\text {th }}$ criterion over $j^{\text {th }}$ criterion.

$$
D_{k i j}=\left[\begin{array}{ccccc}
x_{k 11} & x_{k 12} & x_{k 13} & \ldots & x_{k 1 n} \\
& x_{k 22} & x_{k 23} & \ldots & x_{k 2 n} \\
& & x_{k 33} & \ldots & x_{3 n} \\
& & & \ldots & \ldots \\
& & & & x_{k n n}
\end{array}\right]
$$

Table 2. Fuzzy linguistic scale and membership function.

\begin{tabular}{|c|c|c|c|}
\hline $\begin{array}{c}\text { Linguistic Scale } \\
\left(x_{k i j}\right)\end{array}$ & Saaty Scale & $\begin{array}{c}\text { Fuzzy Membership } \\
\text { Function }\left(l_{i j}, m_{i j}, u_{i j}\right)\end{array}$ & $\begin{array}{c}\text { Fuzzy Reciprocals } \\
\left(1 / u_{i j}, 1 / m_{i j}, 1 / l_{i j}\right)\end{array}$ \\
\hline $\begin{array}{l}\text { Equally important } \\
\text { (EI) }\end{array}$ & 1 & $(1,1,1)$ & $(1,1,1)$ \\
\hline $\begin{array}{l}\text { Moderate important } \\
\text { (MI) }\end{array}$ & 3 & $(2,3,4)$ & $(1 / 4,1 / 3,1 / 2)$ \\
\hline Fairly important (FI) & 5 & $(4,5,6)$ & $(1 / 6,1 / 5,1 / 4)$ \\
\hline $\begin{array}{l}\text { Strongly important } \\
\text { (SI) }\end{array}$ & 7 & $(6,7,8)$ & $(1 / 8,1 / 7,1 / 6)$ \\
\hline $\begin{array}{l}\text { Extremely important } \\
\text { (EI) }\end{array}$ & 9 & $(9,9,9)$ & $(1 / 9,1 / 9,1 / 9)$ \\
\hline \multirow{4}{*}{ Intermediate value } & 2 & $(1,2,3)$ & $(1 / 3,1 / 2,1 / 1)$ \\
\hline & 4 & $(3,4,5)$ & $(1 / 5,1 / 4,1 / 3)$ \\
\hline & 6 & $(5,6,7)$ & $(1 / 7,1 / 6,1 / 5)$ \\
\hline & 8 & $(7,8,9)$ & $(1 / 9,1 / 8,1 / 7)$ \\
\hline
\end{tabular}

\subsubsection{Develop Fuzzy Matrix}

A fuzzy matrix is then developed based on the fuzzy membership and fuzzy reciprocal scales as shown in Table 2. In Equation (2), if $x_{i j}$ is $\left(l_{i j}, m_{i j}, u_{i j}\right)$, then $x_{j i}$ will be $\left(1 / u_{i j}, 1 / m_{i j}\right.$, $\left.1 / l_{i j}\right)$ in the fuzzy matrix, where $i \neq j$.

$$
F_{k i j}=\left[\begin{array}{ccccc}
l_{k 11}, m_{k 11}, u_{k 11} & l_{k 12}, m_{k 12}, u_{k 12} & l_{k 13}, m_{k 13}, u_{k 13} & \ldots & l_{k 1 n}, m_{k 1 n}, u_{k 1 n} \\
l_{k 21}, m_{k 21}, u_{k 21} & l_{k 22}, m_{k 22}, u_{k 22} & l_{k 23}, m_{k 23}, u_{k 23} & \ldots & l_{k 2 n}, m_{k 2 n}, u_{k 2 n} \\
l_{k 31}, m_{k 31}, u_{k 31} & l_{k 32}, m_{k 32}, u_{k 32} & l_{k 33}, m_{k 33}, u_{k 33} & \ldots & l_{k 3 n}, m_{k 3 n}, u_{k 3 n} \\
\ldots & \ldots & \ldots & \ldots & \ldots \\
l_{k n 1}, m_{k n 1}, u_{k n 1} & l_{k n 2}, m_{k n 2}, u_{k n 2} & l_{k n 3}, m_{k n 3}, u_{k n 3} & \ldots & l_{k n n}, m_{k n n}, u_{k n n}
\end{array}\right]
$$

\subsubsection{Aggregate the Matrix}

The fuzzy matrices obtained from the experts are then aggregated by using the geometric mean method (Equation (3)) as discussed in [44]. In Equation (3), $K$ represents the total participating experts.

$$
B_{i j}=\sqrt[K]{\prod_{k=1}^{K} F_{k i j}} \quad \forall F_{k i j} \in\left(l_{k i j}, m_{k i j}, u_{k i j}\right)
$$

\subsubsection{Construct Defuzzified Matrix}

To defuzzify the aggregate fuzzy matrix, the best non-fuzzy performance (BNP) method as proposed by [45] is used.

$$
B N P_{i j}=\frac{\left(u_{i j}-l_{i j}\right)+\left(m_{i j}-l_{i j}\right)}{3}+l_{i j}
$$




\subsubsection{Normalize the Aggregate Matrix}

The score obtained from the BNP method is then normalized using Equation (5).

$$
N_{i j}=\frac{B N P_{i j}}{\sqrt{\sum_{i=1}^{n} B N P_{i j}^{2}}}
$$

\subsubsection{Calculate the Weight of Criteria}

Finally, the weight of the criteria is calculated by using Equation (6). Weight here represents the priority of one criterion over others for achieving green practice in the hotel industry.

$$
W_{i}=\frac{\sum_{i=1}^{n} N_{i j}}{\sum_{i=1}^{n} \sum_{j=1}^{n} N_{i j}}
$$

\subsubsection{Check the Consistency of Pairwise Comparison Matrix}

Consistency of pairwise comparison is very important in the AHP method. To check the expert's consistency during the pairwise comparison consistency ratio is calculated using Equation (7).

$$
C R=\frac{C I}{R I}
$$

where,

$$
C I=\frac{\lambda_{\max }-n}{n-1}
$$

In Equation (8), $\lambda_{\max }$ is the principal eigenvalue of the pairwise comparison matrix, which can be calculated using Equation (9).

$$
\lambda_{\max }=\frac{\sum_{j=1}^{n} B_{i j} W_{j}}{W_{i}}
$$

The consistency ratio (RI) is a constant parameter defined by Saaty the value of which depends on the number of criteria $n$ [46]. In order to accept the pairwise comparison matrix, the consistency ratio should be less than 0.1 [47]. Otherwise, the decision-makers should revise their assessments as inconsistency will violate the principle of transitivity [48].

\subsection{Fuzzy TOPSIS Method}

The Technique for Order of Preference by Similarity to Ideal Solution (TOPSIS) is a multi-criteria decision-making approach that was first proposed by Hwang and Yoon in 1981 [49]. It is used to evaluate multiple alternatives against multiple selected criteria and sub-criteria. Here we propose integrating fuzzy logic with the TOPSIS method to deal with the vagueness and uncertainty in human judgment during the decision-making process. The fuzzy TOPSIS is selected here because it is simpler and realistic. Moreover, it is widely used due to its clear methodology and easily programmable computation procedure [42]; Ref [50] in this research, the weight obtained from Section 3.2 is integrated with the fuzzy TOPSIS method to develop the GSCM index for ranking the alternatives. It involves the following steps:

\subsubsection{Develop Fuzzy Decision Matrix for Ranking Alternatives}

Once the alternative for the ranking is identified, develop a matrix using the linguistic term. The matrix in Equation (9) shows the performance of alternatives on GP criteria. In the equation, $y_{i f}$ represents the linguistic scale on the implementation of criteria $i=1,2, \ldots$, $n$ at alternate $f=1,2, \ldots, F$. The performance is defined in terms of the linguistic variable 
corresponding to the 5-point Likert scale as defined by [51]. The scales and triangular membership functions used are as shown in Table 3.

$$
\begin{gathered}
D_{k}=\left[\begin{array}{ccccc}
y_{11} & y_{12} & y_{13} & \ldots & y_{1 F} \\
y_{21} & y_{22} & y_{23} & \ldots & y_{2 F} \\
y_{31} & y_{32} & y_{33} & \ldots & y_{3 F} \\
\ldots & \ldots & \ldots & \ldots & \ldots \\
y_{n 1} & y_{n 2} & y_{n 3} & \ldots & y_{n F}
\end{array}\right] \\
y_{i f}=\left(l_{i f}, m_{i f}, u_{i f}\right)
\end{gathered}
$$

Table 3. Fuzzy scale and membership function for ranking alternatives.

\begin{tabular}{ccc}
\hline Linguistic Scale $\left(y_{i f}\right)$ & Likert Scale & $\begin{array}{c}\text { Fuzzy Membership Function } \\
\left(\boldsymbol{l}_{\boldsymbol{i}}, \boldsymbol{m}_{\boldsymbol{i}}, \boldsymbol{u}_{i f}\right)\end{array}$ \\
\hline Very poor (VP) & 1 & $(0,1,3)$ \\
\hline Poor (P) & 2 & $(1,3,5)$ \\
\hline Medium (M) & 3 & $(3,5,7)$ \\
\hline Good (G) & 4 & $(5,7,9)$ \\
\hline Very Good (VG) & 5 & $(7,9,10)$ \\
\hline
\end{tabular}

\subsubsection{Normalize the Fuzzy Decision Matrix}

The decision matrix is normalized by using Equation (11) and the normalized matrix is represented by $R=\left[r_{i f}\right]_{n \times F}, i=1,2 \ldots, n ; f=1,2, \ldots, F$.

$$
\begin{gathered}
r_{i f}=\left(\frac{l_{i f}}{u_{f}^{+}}, \frac{m_{i f}}{u_{f}^{+}}, \frac{u_{i f}}{u_{f}^{+}}\right) \\
u_{f}^{+}=\max _{i}\left(u_{i j} \mid i=1,2, \ldots, n\right)
\end{gathered}
$$

\subsubsection{Compute the Weighted Normalized Fuzzy Decision Matrix}

A weighted normalized fuzzy decision matrix is then obtained by using Equation (13) and is expressed by $\widetilde{V}=\left[\widetilde{v}_{i f}\right]_{n \times F}, i=1,2 \ldots, n ; f=1,2, \ldots, F$. In the equation, $w_{i}$ represents the criteria weight obtained from Section 3.2.

$$
\widetilde{v}_{i f}=r_{i f} * w_{i}
$$

\subsubsection{Calculate the Fuzzy Positive-Ideal Solution and Fuzzy Negative-Ideal Solution}

The fuzzy positive-ideal solution (FPSI) and fuzzy negative-ideal solution (FNSI) on the given criterion represent the maximum and the minimum values, respectively, obtained from the weighted normalized fuzzy decision matrix, among all the alternates. It is calculated by using Equation (14) and Equation (15) respectively.

$$
\begin{aligned}
& A_{i}^{+}=\left(\max _{i} \widetilde{v}_{i f} \mid f \in F\right)=\left(v_{1}^{+}, v_{2}^{+}, \ldots, v_{n}^{+}\right) \\
& A_{i}^{-}=\left(\min _{i} \widetilde{v}_{i f} \mid f \in F\right)=\left(v_{1}^{-}, v_{2}^{-}, \ldots, v_{n}^{-}\right)
\end{aligned}
$$




\subsubsection{Calculate the Euclidian Distance}

The Euclidian distance of each alternative is calculated from FPIS and FNIS by using Equation (16) and Equation (17) respectively.

$$
\begin{aligned}
& d_{f}^{+}=\sum_{i=1}^{n} \sqrt{\frac{1}{3}\left\{\left(\widetilde{l}_{i f}-A_{i}^{+}\right)^{2}+\left(\widetilde{m}_{i f}-A_{i}^{+}\right)^{2}+\left(\widetilde{u}_{i f}-A_{i}^{+}\right)^{2}\right\}} ; f=1,2, \ldots, F \\
& d_{f}^{-}=\sum_{i=1}^{n} \sqrt{\frac{1}{3}\left\{\left(\widetilde{l}_{i f}-A_{i}^{-}\right)^{2}+\left(\widetilde{m}_{i f}-A_{i}^{-}\right)^{2}+\left(\widetilde{u}_{i f}-A_{i}^{-}\right)^{2}\right\}} ; f=1,2, \ldots, F
\end{aligned}
$$

In Equations (16) and (17), $\left(\widetilde{l}_{i f}, \widetilde{m}_{i f}, \widetilde{u}_{i f}\right) \in v_{i f}$.

\subsubsection{Calculate the Closeness Coefficient}

The closeness coefficient for each alternative option is calculated by using Equation (18), where $0 \leq C C_{f} \leq 1$. The closeness coefficient represents the green score achieved by the alternative.

$$
C C_{f}=\frac{d_{f}^{-}}{d_{f}^{+}+d_{f}^{-}}, f=1,2, \ldots, F
$$

\section{Case Study}

A case study is conducted to check the applicability of the proposed integrated approach and rank the hotels in the Sultanate of Oman. For the case study, data were gathered from the ministry of tourism and star hotels in Oman through an online survey. To encourage participation in the survey, people at the ministry of tourism and hotel managers were contacted by phone call, email, and virtual meeting. The data were collected from people working at the managerial level who have more than 10 years of experience working in the hospitality sector.

\subsection{Hotel Industry in Oman}

Oman's economy is largely supported by the oil and gas industries [52]. However, the government is putting significant effort to improve the tourism sector as an alternate source of the economy away from oil and gas. Therefore, the hotel industry has a major role in the effort of government for the economic diversification. Oman's hospitality industry is projected to expand at a compound annual growth rate (CAGR) between 2017 and 2022 from 7.5 percent to USD 1 billion according to the GCC Hospitality Industry Report released by investment banking consulting company Alpen Capital. This study also forecasts a rise in international visitor stays at a 5-year CAGR from 1.3 percent to 3.4 million, while hotel availability is projected to expand to approximately 29,635 hotel rooms in 2022 at a 5 -year CAGR of 5.6 percent. According to the available information from the ministry of tourism, the total number of star hotels in Oman stands at 221 without including resorts and hostels. The number of hotels in each star category is shown in Table 4.

Table 4. Number of hotels in Oman.

\begin{tabular}{cccc}
\hline Hotel Rating & Number of Hotels & Hotel Rating & Number of Hotels \\
\hline 5-Star & 26 & 2-Star & 55 \\
\hline 4-Star & 23 & 1-Star & 79 \\
\hline 3-Star & 38 & & \\
\hline
\end{tabular}

\subsection{Criteria Weight}

To calculate the weight for the identified six criteria as discussed in Section 3.1 Fuzzy AHP method is implemented. Six experts were contacted to collect information pertaining 
to the pairwise comparison of criteria and develop the pairwise comparison matrix. The experts were provided with a comparison matrix and requested to fill the matrix using the Satty scale as shown in Table 2. Out of six, three experts were from the ministry, and the remaining worked at star hotels. Therefore, a total of six pairwise comparison matrices were obtained, a sample received from one of the experts is as shown in Table 5.

Table 5. Pairwise comparison matrix.

\begin{tabular}{ccccccc}
\hline Criteria & C1 & C2 & C3 & C4 & C5 & C6 \\
\hline C1 & 1 & 1 & 4 & 1 & 2 & 4 \\
\hline C2 & - & 1 & 4 & 1 & 2 & 4 \\
\hline C3 & - & - & 1 & 4 & 3 & 1 \\
\hline C4 & - & - & - & 1 & 2 & 4 \\
\hline C5 & - & - & - & - & 1 & 3 \\
\hline C6 & - & - & - & - & - & 1 \\
\hline
\end{tabular}

Next, the matrix obtained from the experts was converted into a fuzzy matrix using the fuzzy membership function and its reciprocal. Table 6 shows the fuzzy matrix obtained for Table 5.

Table 6. Fuzzy pairwise comparison matrix.

\begin{tabular}{|c|c|c|c|c|c|c|}
\hline Criteria & $\mathrm{C} 1$ & $\mathrm{C} 2$ & $\mathrm{C} 3$ & $\mathrm{C} 4$ & C5 & C6 \\
\hline $\mathrm{C} 1$ & 1 & $(1,1,1)$ & $(3,4,5)$ & $(1,1,1)$ & $(1,2,3)$ & $(3,4,5)$ \\
\hline $\mathrm{C} 2$ & $(1,1,1)$ & 1 & $(3,4,5)$ & $(1,1,1)$ & $(1,2,3)$ & $(3,4,5)$ \\
\hline $\mathrm{C} 3$ & $\begin{array}{c}(0.20,0.25 \\
0.33)\end{array}$ & $\begin{array}{c}(0.20,0.25 \\
0.33)\end{array}$ & 1 & $(3,4,5)$ & $(2,3,4)$ & $(1,1,1)$ \\
\hline $\mathrm{C} 4$ & $(1,1,1)$ & $(1,1,1)$ & $\begin{array}{c}(0.20,0.25 \\
0.33)\end{array}$ & 1 & $(1,2,3)$ & $(3,4,5)$ \\
\hline C5 & $\begin{array}{c}(0.33,0.50 \\
1.0)\end{array}$ & $\begin{array}{c}(0.33,0.50 \\
1.0)\end{array}$ & $\begin{array}{c}(0.25,0.33 \\
0.50)\end{array}$ & $\begin{array}{c}(0.33,0.50 \\
1.0)\end{array}$ & 1 & $(2,3,4)$ \\
\hline C6 & $\begin{array}{c}(0.20,0.25 \\
0.33)\end{array}$ & $\begin{array}{c}(0.20,0.25 \\
0.33)\end{array}$ & $(1,1,1)$ & $\begin{array}{c}(0.20,0.25 \\
0.33)\end{array}$ & $\begin{array}{c}(0.25,0.33, \\
0.50)\end{array}$ & 1 \\
\hline
\end{tabular}

Table 7 shows the unified matrix based on the fuzzy pairwise comparison matrix obtained from all six experts. The unification is done by using a geometric mean method as discussed in Section 3.2.4.

The pairwise comparison matrix is then checked for consistency. It was found that the consistency ratio (CR) of the unified pairwise comparison matrix is 0.09 . Since the value of $\mathrm{CR}<0.1$, the matrix is consistent.

Finally, the weight of the criteria was identified from the normalized aggregate matrix (Table 8). The weights are shown in Table 9 below. In the table, the local weight for the indicators was also enumerated. It should be noted that the same steps as followed to identify the criteria weight were followed to identify the local weight of the indicators for the given criteria. Further, global weight is calculated by multiplying the weight of criteria with the local weight. The result shows that criteria $\mathrm{C} 1$ has the highest ranking in terms of weight, which is followed by $\mathrm{C} 2$ and then $\mathrm{C} 4$. On the other hand, criteria $\mathrm{C} 6$ has the least weight. At the global level, indicators SC12 and SC13 have the highest weight and SC35 has the least weight. 
Table 7. Unified fuzzy pairwise comparison matrix.

\begin{tabular}{|c|c|c|c|c|c|c|}
\hline Criteria & $\mathrm{C} 1$ & $\mathrm{C} 2$ & $\mathrm{C} 3$ & $\mathrm{C} 4$ & C5 & C6 \\
\hline $\mathrm{C} 1$ & 1 & $(1,2,3)$ & $\begin{array}{c}(1.5,3.2 \\
6.3)\end{array}$ & $\begin{array}{c}(1.2,1.4 \\
1.8)\end{array}$ & $\begin{array}{c}(1.3,2.5 \\
6.0)\end{array}$ & $\begin{array}{c}(1.0,2.0, \\
3.0)\end{array}$ \\
\hline $\mathrm{C} 2$ & $\begin{array}{c}(0.3,0.5 \\
1.0)\end{array}$ & 1 & $\begin{array}{c}(1.0,2.4 \\
5.0)\end{array}$ & $\begin{array}{c}(1.2,1.6 \\
2.3)\end{array}$ & $\begin{array}{c}(1.3,2.5 \\
6.0)\end{array}$ & $\begin{array}{c}(1.5,3.6 \\
6.8)\end{array}$ \\
\hline $\mathrm{C} 3$ & $\begin{array}{c}(0.3,0.3 \\
0.5)\end{array}$ & $\begin{array}{c}(0.2,0.4 \\
0.8)\end{array}$ & 1 & $\begin{array}{c}(1.3,2.5 \\
6.0)\end{array}$ & $\begin{array}{c}(1.0,2.4 \\
5.0)\end{array}$ & $\begin{array}{c}(1.2,1.6 \\
2.3)\end{array}$ \\
\hline $\mathrm{C} 4$ & $\begin{array}{c}(0.3,0.7 \\
0.5)\end{array}$ & $\begin{array}{c}(0.3,0.6 \\
1.0)\end{array}$ & $\begin{array}{c}(0.2,0.4 \\
0.8)\end{array}$ & 1 & $\begin{array}{c}(1.5,1.8 \\
2.3)\end{array}$ & $\begin{array}{c}(2.0,3.0 \\
4.0)\end{array}$ \\
\hline C5 & $\begin{array}{c}(0.2,0.4 \\
0.8)\end{array}$ & $\begin{array}{c}(0.2,0.4 \\
0.8)\end{array}$ & $\begin{array}{c}(0.2,0.4 \\
0.8)\end{array}$ & $\begin{array}{c}(0.3,0.6 \\
1.0)\end{array}$ & 1 & $\begin{array}{c}(1.3,2.5 \\
6.0)\end{array}$ \\
\hline C6 & $\begin{array}{c}(0.3,0.5 \\
1.0)\end{array}$ & $\begin{array}{c}(0.3,0.3 \\
0.5)\end{array}$ & $\begin{array}{c}(0.3,0.6 \\
1.0)\end{array}$ & $\begin{array}{c}(0.3,0.3 \\
0.5)\end{array}$ & $\begin{array}{c}(0.2,0.4 \\
0.8)\end{array}$ & 1 \\
\hline
\end{tabular}

Table 8. Normalized aggregate matrix.

\begin{tabular}{ccccccc}
\hline Criteria & $\mathbf{1}$ & $\mathbf{2}$ & $\mathbf{3}$ & $\mathbf{4}$ & $\mathbf{5}$ & $\mathbf{6}$ \\
\hline 1 & 0.19 & 0.82 & 0.76 & 0.35 & 0.56 & 0.30 \\
\hline 2 & 0.12 & 0.41 & 0.58 & 0.41 & 0.56 & 0.60 \\
\hline 3 & 0.07 & 0.19 & 0.21 & 0.79 & 0.48 & 0.26 \\
\hline 4 & 0.96 & 0.26 & 0.10 & 0.24 & 0.32 & 0.46 \\
\hline 5 & 0.09 & 0.19 & 0.10 & 0.15 & 0.17 & 0.50 \\
\hline 6 & 0.12 & 0.15 & 0.13 & 0.09 & 0.08 & 0.15 \\
\hline
\end{tabular}

Table 9. Weight for the criteria and the indicators.

\begin{tabular}{|c|c|c|c|c|}
\hline Criteria & $\begin{array}{l}\text { Weight of } \\
\text { Criteria }\end{array}$ & Indicator & $\begin{array}{l}\text { Local Weight of } \\
\text { Indicator }\end{array}$ & Global Weight \\
\hline \multirow{3}{*}{$\mathrm{C} 1$} & \multirow{3}{*}{0.25} & SC11 & 0.27 & 0.07 \\
\hline & & SC12 & 0.35 & 0.09 \\
\hline & & SC13 & 0.38 & 0.09 \\
\hline \multirow{3}{*}{$\mathrm{C} 2$} & \multirow{3}{*}{0.22} & SC21 & 0.38 & 0.08 \\
\hline & & $\mathrm{SC} 22$ & 0.32 & 0.07 \\
\hline & & $\mathrm{SC} 23$ & 0.29 & 0.06 \\
\hline \multirow{9}{*}{$\mathrm{C} 3$} & \multirow{9}{*}{0.17} & SC31 & 0.11 & 0.02 \\
\hline & & SC32 & 0.12 & 0.02 \\
\hline & & SC33 & 0.12 & 0.02 \\
\hline & & SC34 & 0.09 & 0.02 \\
\hline & & SC35 & 0.07 & 0.01 \\
\hline & & SC36 & 0.12 & 0.02 \\
\hline & & SC37 & 0.12 & 0.02 \\
\hline & & SC38 & 0.14 & 0.02 \\
\hline & & SC39 & 0.12 & 0.02 \\
\hline
\end{tabular}


Table 9. Cont.

\begin{tabular}{|c|c|c|c|c|}
\hline Criteria & $\begin{array}{l}\text { Weight of } \\
\text { Criteria }\end{array}$ & Indicator & $\begin{array}{l}\text { Local Weight of } \\
\text { Indicator }\end{array}$ & Global Weight \\
\hline \multirow{5}{*}{$\mathrm{C} 4$} & \multirow{5}{*}{0.20} & SC41 & 0.22 & 0.04 \\
\hline & & SC42 & 0.24 & 0.05 \\
\hline & & SC43 & 0.20 & 0.04 \\
\hline & & SC44 & 0.11 & 0.02 \\
\hline & & SC45 & 0.24 & 0.05 \\
\hline \multirow{3}{*}{ C5 } & \multirow{3}{*}{0.10} & SC51 & 0.34 & 0.03 \\
\hline & & SC52 & 0.31 & 0.03 \\
\hline & & SC53 & 0.35 & 0.04 \\
\hline \multirow{3}{*}{ C6 } & \multirow{3}{*}{0.06} & SC61 & 0.38 & 0.02 \\
\hline & & SC62 & 0.33 & 0.02 \\
\hline & & SC63 & 0.30 & 0.02 \\
\hline
\end{tabular}

\subsection{Green Score of Hotel}

Next, to understand the green implementation in the hotel industry in Oman, the green scores of hotels were calculated based on the fuzzy TOPSIS method as discussed in Section 3.3. To collect data for calculating score the questionnaire survey was prepared as shown in Appendix A. To make it easier for the participant, as shown in the questionnaire, the indicators were ranked using a 5-point Likert scale ranging from "very poor" to "very high" [51]. Each scale range has a fuzzy membership function associated with it. The google survey link pertaining to this survey was forwarded to all the four-star and five-star hotels in Oman assuming that these hotels will have well-established sustainability frameworks. Thereafter, the managers of the hotels were communicated to request them to fill up the survey. The authors were able to communicate with the manager of only around $50 \%$ of the hotels. In the communication, it was requested that the survey be filled by three employees independently from each hotel. Complete survey data were obtained from thirteen hotels out of which eight were 5-star hotels and the remaining five were 4-star hotels. This results in 39 data sets and $26.5 \%$ coverage among available targeted hotels. Results from the survey are then used to find the green score for each hotel. For each hotel, the data obtained from three individual employees are integrated using the geometric mean method as discussed in Equation (3). For the sake of confidentiality, these hotels are represented as H1-H13.

The third column in Table 10 shows the sample data received from three experts of one of the hotels that participated in the survey. The data is received in the form of the linguistic variable. The data is translated into fuzzy membership function and unified after integrating the data from three experts. The unified fuzzy membership function is then normalized, and the resulting data is multiplied with the global weight to obtain a weighted normalized fuzzy matrix. Thereafter, FPIS and FNIS are computed. Here, it should be noted that the FPSI and FNIS are based on the data received from all the participating hotels. Then, based on the weighted normalized values and the FPIS and FNIS, Euclidian distances were computed for the sample hotel. The total positive $\left(d^{+}\right)$and negative $\left(d^{-}\right)$ Euclidian distances of sample hotels are 0.023 and 0.051 respectively. This resulted in the green score of the sample hotel being 0.691 . 
Table 10. Sample data and necessary calculations.

\begin{tabular}{|c|c|c|c|c|c|c|c|c|c|c|c|c|c|c|c|c|c|c|c|c|c|}
\hline \multirow[t]{2}{*}{ Criteria } & \multirow[t]{2}{*}{ Indicator } & \multicolumn{3}{|c|}{$\begin{array}{l}\text { Linguistic } \\
\text { Variable }\end{array}$} & \multicolumn{3}{|c|}{$\begin{array}{l}\text { Unified Fuzzy } \\
\text { Membership } \\
\text { Function }\end{array}$} & \multicolumn{3}{|c|}{$\begin{array}{l}\text { Normalized Fuzzy } \\
\text { Value }\end{array}$} & \multicolumn{3}{|c|}{$\begin{array}{c}\text { Weighted } \\
\text { Normalized Fuzzy } \\
\text { Value }\end{array}$} & \multicolumn{3}{|c|}{ FPIS } & \multicolumn{3}{|c|}{ FNIS } & \multicolumn{2}{|c|}{$\begin{array}{c}\text { Euclidian } \\
\text { Distance }\end{array}$} \\
\hline & & E1 & E2 & E3 & $l$ & $m$ & $u$ & $l$ & $m$ & $u$ & $l$ & $m$ & $u$ & $l$ & $m$ & $u$ & $l$ & $m$ & $u$ & $d^{+}$ & $d^{-}$ \\
\hline \multirow{4}{*}{$\mathrm{C} 1$} & SC11 & $\mathrm{M}$ & $\mathrm{M}$ & $\mathrm{M}$ & 3.00 & 5.00 & 7.00 & 0.35 & 0.58 & 0.81 & 0.023 & 0.039 & 0.054 & 0.039 & 0.055 & 0.067 & 0.018 & 0.034 & 0.049 & & \\
\hline & SC12 & G & $\mathrm{M}$ & G & 4.33 & 6.33 & 8.33 & 0.52 & 0.76 & 1.00 & 0.046 & 0.067 & 0.088 & 0.046 & 0.067 & 0.088 & 0.032 & 0.053 & 0.074 & & \\
\hline & SC13 & VG & M & G & 5.00 & 7.00 & 8.67 & 0.54 & 0.75 & 0.93 & 0.051 & 0.071 & 0.088 & 0.058 & 0.077 & 0.094 & 0.051 & 0.071 & 0.088 & & \\
\hline & & & & & & & & & & & 0.120 & 0.177 & 0.230 & 0.128 & 0.185 & 0.236 & 0.115 & 0.172 & 0.225 & 0.008 & 0.005 \\
\hline \multirow{4}{*}{$\mathrm{C} 2$} & $\mathrm{SC} 21$ & $\mathrm{M}$ & G & $\mathrm{M}$ & 3.67 & 5.67 & 7.67 & 0.48 & 0.74 & 1.00 & 0.000 & 0.009 & 0.084 & 0.040 & 0.062 & 0.084 & 0.033 & 0.055 & 0.073 & & \\
\hline & SC22 & M & $\mathrm{P}$ & M & 2.33 & 4.33 & 6.33 & 0.33 & 0.62 & 0.90 & 0.007 & 0.000 & 0.064 & 0.031 & 0.051 & 0.071 & 0.024 & 0.044 & 0.064 & & \\
\hline & $\mathrm{SC} 23$ & VG & VG & $\mathrm{P}$ & 5.00 & 7.00 & 8.33 & 0.54 & 0.75 & 0.89 & 0.006 & 0.004 & 0.058 & 0.039 & 0.053 & 0.065 & 0.030 & 0.044 & 0.055 & & \\
\hline & & & & & & & & & & & 0.099 & 0.155 & 0.206 & 0.103 & 0.158 & 0.209 & 0.087 & 0.143 & 0.193 & 0.004 & 0.012 \\
\hline \multirow{10}{*}{$\mathrm{C} 3$} & SC31 & $M$ & M & $G$ & 3.67 & 5.67 & 7.67 & 0.44 & 0.68 & 0.92 & 0.001 & 0.000 & 0.017 & 0.010 & 0.014 & 0.018 & 0.008 & 0.012 & 0.017 & & \\
\hline & SC32 & $\mathrm{P}$ & G & $\mathrm{M}$ & 3.00 & 5.00 & 7.00 & 0.33 & 0.56 & 0.78 & 0.005 & 0.001 & 0.015 & 0.012 & 0.017 & 0.020 & 0.005 & 0.009 & 0.014 & & \\
\hline & SC33 & $\mathrm{M}$ & G & $\mathrm{M}$ & 3.67 & 5.67 & 7.67 & 0.46 & 0.71 & 0.96 & 0.001 & 0.003 & 0.019 & 0.011 & 0.016 & 0.020 & 0.007 & 0.011 & 0.016 & & \\
\hline & SC34 & $\mathrm{G}$ & VG & $\mathrm{P}$ & 4.00 & 5.67 & 7.33 & 0.40 & 0.57 & 0.73 & 0.005 & 0.000 & 0.011 & 0.011 & 0.014 & 0.016 & 0.006 & 0.009 & 0.011 & & \\
\hline & SC35 & VG & G & $\mathrm{M}$ & 5.00 & 7.00 & 8.67 & 0.58 & 0.81 & 1.00 & 0.000 & 0.002 & 0.011 & 0.007 & 0.009 & 0.011 & 0.004 & 0.007 & 0.009 & & \\
\hline & SC36 & $\mathrm{M}$ & $\mathrm{P}$ & VG & 3.67 & 5.67 & 7.33 & 0.48 & 0.74 & 0.96 & 0.002 & 0.008 & 0.020 & 0.013 & 0.017 & 0.021 & 0.003 & 0.006 & 0.012 & & \\
\hline & SC37 & $\mathrm{M}$ & M & G & 3.67 & 5.67 & 7.67 & 0.42 & 0.65 & 0.88 & 0.003 & 0.000 & 0.018 & 0.011 & 0.016 & 0.020 & 0.008 & 0.013 & 0.018 & & \\
\hline & SC38 & VG & VG & G & 6.33 & 8.33 & 9.67 & 0.66 & 0.86 & 1.00 & 0.000 & 0.006 & 0.023 & 0.015 & 0.020 & 0.023 & 0.009 & 0.014 & 0.018 & & \\
\hline & SC39 & G & G & VG & 5.67 & 7.67 & 9.33 & 0.59 & 0.79 & 0.97 & 0.001 & 0.003 & 0.020 & 0.014 & 0.018 & 0.021 & 0.010 & 0.014 & 0.018 & & \\
\hline & & & & & & & & & & & 0.083 & 0.121 & 0.155 & 0.089 & 0.126 & 0.158 & 0.076 & 0.113 & 0.145 & 0.005 & 0.008 \\
\hline \multirow{6}{*}{$\mathrm{C} 4$} & SC41 & $\mathrm{P}$ & VG & VG & 5.00 & 7.00 & 8.33 & 0.60 & 0.84 & 1.00 & 0.000 & 0.013 & 0.043 & 0.026 & 0.036 & 0.043 & 0.012 & 0.023 & 0.033 & & \\
\hline & SC42 & M & G & $\mathrm{P}$ & 3.00 & 5.00 & 7.00 & 0.33 & 0.56 & 0.78 & 0.011 & 0.006 & 0.037 & 0.026 & 0.037 & 0.047 & 0.011 & 0.019 & 0.030 & & \\
\hline & SC43 & G & M & M & 3.67 & 5.67 & 7.67 & 0.42 & 0.65 & 0.88 & 0.006 & 0.000 & 0.036 & 0.023 & 0.033 & 0.040 & 0.017 & 0.026 & 0.036 & & \\
\hline & SC44 & G & VG & VG & 6.33 & 8.33 & 9.67 & 0.66 & 0.86 & 1.00 & 0.000 & 0.008 & 0.022 & 0.014 & 0.019 & 0.022 & 0.005 & 0.010 & 0.014 & & \\
\hline & SC45 & VG & $\mathrm{M}$ & $\mathrm{P}$ & 3.67 & 5.67 & 7.33 & 0.39 & 0.61 & 0.79 & 0.010 & 0.010 & 0.037 & 0.029 & 0.039 & 0.047 & 0.009 & 0.018 & 0.029 & & \\
\hline & & & & & & & & & & & 0.092 & 0.136 & 0.175 & 0.092 & 0.136 & 0.175 & 0.078 & 0.121 & 0.162 & 0.000 & 0.014 \\
\hline \multirow{4}{*}{ C5 } & SC51 & G & G & M & 4.33 & 6.33 & 8.33 & 0.52 & 0.76 & 1.00 & 0.000 & 0.013 & 0.034 & 0.017 & 0.026 & 0.034 & 0.004 & 0.012 & 0.020 & & \\
\hline & SC52 & VP & G & VP & 1.67 & 3.00 & 5.00 & 0.18 & 0.32 & 0.54 & 0.014 & 0.000 & 0.017 & 0.019 & 0.025 & 0.031 & 0.006 & 0.010 & 0.017 & & \\
\hline & SC53 & $\mathrm{M}$ & VG & G & 5.00 & 7.00 & 8.67 & 0.58 & 0.81 & 1.00 & 0.000 & 0.005 & 0.035 & 0.020 & 0.029 & 0.035 & 0.015 & 0.023 & 0.030 & & \\
\hline & & & & & & & & & & & 0.043 & 0.064 & 0.086 & 0.049 & 0.071 & 0.092 & 0.038 & 0.061 & 0.083 & 0.006 & 0.004 \\
\hline \multirow{4}{*}{ C6 } & SC61 & $\mathrm{M}$ & G & VG & 5.00 & 7.00 & 8.67 & 0.56 & 0.78 & 0.96 & 0.000 & 0.003 & 0.022 & 0.013 & 0.018 & 0.023 & 0.009 & 0.014 & 0.019 & & \\
\hline & SC62 & $\mathrm{P}$ & VG & $\mathrm{M}$ & 3.67 & 5.67 & 7.33 & 0.50 & 0.77 & 1.00 & 0.000 & 0.005 & 0.020 & 0.010 & 0.015 & 0.020 & 0.004 & 0.010 & 0.015 & & \\
\hline & SC63 & $\mathrm{M}$ & VG & G & 5.00 & 7.00 & 8.67 & 0.54 & 0.75 & 0.93 & 0.001 & 0.005 & 0.017 & 0.011 & 0.015 & 0.018 & 0.005 & 0.008 & 0.011 & & \\
\hline & & & & & & & & & & & 0.032 & 0.046 & 0.058 & 0.032 & 0.046 & 0.058 & 0.024 & 0.039 & 0.052 & 0.00 & 0.007 \\
\hline
\end{tabular}

Similar steps as discussed above are performed for the remaining hotels and the green scores are computed. The green score and ranking of participating hotels are shown in Table 11. The table shows that the highest green score is achieved by Hotel (H7) with a score of 0.743 and the lowest one by Hotel (H3) with a score of 0.447 . Both the highest and lowest scores are obtained for $5^{*}$ hotels. It means that higher-star hotel does not necessarily mean that they are the best in terms of green implementation. Further, it can be seen that around $60 \%$ of the hotels have green scores in the range of 0.5 and they are very close to each other. The result shows that the participating hotels have plenty of scope to improve themselves in terms of green practice to increase green score. 
Table 11. Green score and hotel ranking.

\begin{tabular}{cccc}
\hline Hotel & Star & Green Score & Ranking \\
\hline H1 & & 0.691 & Rank 2 \\
H2 & & 0.548 & Rank 11 \\
H3 & 0.447 & Rank 12 \\
H4 & & 0.573 & Rank 7 \\
H5 & 0.569 & Rank 9 \\
H6 & 0.628 & Rank 5 \\
H7 & & 0.743 & Rank 1 \\
H8 & & 0.601 & Rank 6 \\
H9 & & 0.645 & Rank 4 \\
H10 & 0.569 & Rank 9 \\
H11 & & 0.570 & Rank 8 \\
H12 & & 0.559 & Rank 10 \\
H13 & & 0.662 & Rank 3 \\
\hline
\end{tabular}

To make a judgment about the overall green practice at 4-star and 5-star hotels in the Sultanate of Oman, the overall green score is obtained by using two-tail confidence bounds at $95 \%$ CI.

$$
95 \% C I=\bar{X}+Z_{\alpha / 2} * \frac{\sigma}{\sqrt{n}}
$$

In the equation, $\bar{X}$ is the mean of the green scores, $Z_{\alpha / 2}$ is equal to 1.96 at $95 \%$ confidence level, $\sigma$ is the standard deviation of the green scores and $n$ is the sample size from where data are collected. Based on the equation, $\mathrm{CI}=0.60 \pm 0.041$. Therefore, the green score of 4-star and 5-star hotels in the Sultanate of Oman varies between 0.560 and 0.641 at a $95 \%$ CI.

\subsection{Analysis of Indicator}

Further, in order to identify the areas which need improvement to improve the green score, the satisfaction level (SL) achieved for each indicator is calculated using Equation (20). The $S L$ shows the percentage contribution of indicators in the green performance. Such information helps hotels to identify the area where they need to work on to improve the green score.

$$
S L_{i j}=\frac{d_{i}\left(\widetilde{v}_{i j}, \widetilde{v}_{j}^{-}\right)}{d_{i}\left(\widetilde{v}_{i j,} \widetilde{v}_{j}^{+}\right)+d_{i}\left(\widetilde{v}_{i j,} \widetilde{v}_{j}^{-}\right)}, i=1,2, \ldots n ; j=1,2, \ldots, m
$$

As an example, Figure 3 shows the percentage distribution of indicators of green practice in the green performance of the hotel (H3). It can be observed that SC41, SC42, and SC43 have the lowest contribution in the green performance. On the other hand, SC44 has the highest contribution. Coincidentally, both the lowest as well as highest contributors of green performance are related to the criteria of water efficiency and conservation. Apart from SC44, the next highest contributor is SC61, which is related to the criteria of green training and incentives. It should be noted that each hotel may have different indicators or criteria to improve in order to increase its green performance. 


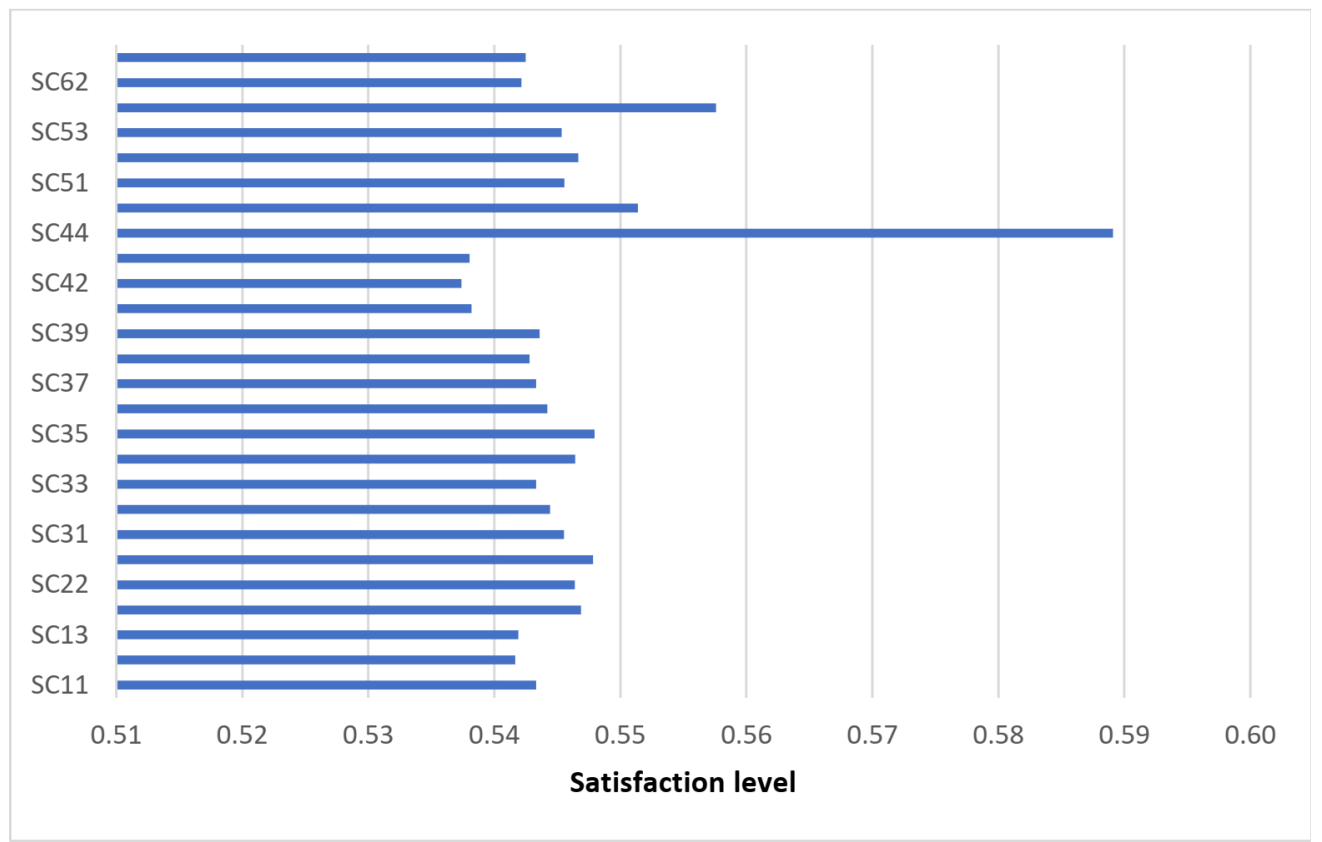

Figure 3. SL score of each indicator for hotel H3.

\section{Conclusions}

The hospitality industry is one of the major pillars of the Tourism Supply Chain. Due to the heightened awareness of climate change, all types of industries are under pressure to minimize the waste they create and its impact on the environment and hotel industry is not an expectation. One way to achieve this objective is through the green practice which includes the concept of reduce, reuse, and recycle, apart from using green products and improving green awareness among stakeholders. The research aims at understanding the factors that affect green practice in the hotel industry and then developing a model that can be used to calculate the green score. To accomplish these objectives, the paper identifies six criteria of green practice through literature survey and experts opinion. Further, for each criterion, multiple indicators were defined to make it easy to compute the level of accomplishment of a given criterion at a specific hotel. Based on the identified indicators and criteria, a novel fuzzy AHP-TOPSIS method is proposed to calculate the Green score of the hotel. The fuzzy AHP method is used to calculate the weight of the criteria and indicators, while the fuzzy TOPSIS method is used to calculate the green score and rank hotels.

To demonstrate the applicability of the proposed method, a case study is conducted by collecting necessary data pertaining to the hotel industry in the Sultanate of Oman. In the case study, at first, the weight of the criteria and indicators were identified. The result shows that criterion "Recycling and Reuse" has the highest weight and "Green Training and Incentives" has the lowest weight. In terms of indicators, SC12 and SC13 have the highest global weights. These indicators are related to the criterion "Recycling and Reuse". On the other hand, indicator SC35 has the lowest global weight. This indicator is related to the criterion "Energy efficiency and conservation". Next, this result is integrated with the fuzzy TOPSIS method to evaluate the green performance of hotels situated in Oman. Thirteen hotels with 4-star and 5-star rankings took part in this study. From each hotel, data from three experts were collected, and the proposed integrated method is implemented to calculate their green score. The result shows that the green score of these hotels varies in between the range of 0.440 to 0.743 . From the result, it is clear that higher-ranking hotel in terms of stars does not necessarily mean that they are best in the implementation of green practices. Further, the result shows that the green score of 4-star and 5-star hotels in the Sultanate of Oman lies in between 0.56 and 0.641 at a $95 \%$ CI. The proposed method can 
also be used to know the indicator where the hotel has to improve in order to improve their green score.

In this paper, the green score is calculated based on the integrated fuzzy AHP-TOPSIS method. There are many other MCDM approaches. It may be interesting to implement other MCDM approaches and compare the result of this research work with these approaches. Moreover, research has shown that there exist relationships between green practice and sustainable development [53]. One interesting area of research expansion can be to empirically check the effect of green practice on the performance of three pillars (ecological, economic, and social) of sustainability.

Author Contributions: The research was conceptualized, designed, and performed by S.P. The original draft of the paper was written by S.P. and A.S. N.A.-H. supported in the collection of necessary data. Finally, the paper was reviewed, edited, and improved by M.A., N.A.-H. and B.E. All authors have read and agreed to the published version of the manuscript.

Funding: This research was funded by [SQU Internal Grant] grant number [IG/ ENG/ MIED/ 21/03].

Institutional Review Board Statement: Not applicable.

Informed Consent Statement: Not applicable.

Data Availability Statement: Not applicable.

Acknowledgments: The authors gratefully acknowledge the efforts and supports of Buthaina Al Qassabi, Aiman Al Mahrouqi, and Aws Amur Alhajri when conducting this study and preparing the report.

Conflicts of Interest: The authors declare no conflict of interest.

\section{Appendix A. Questionnaire for Green Practice at Hotel Industry}

This survey is to check level of Green Practice implemented at your esteemed hotel. The Green practice is defined in terms of six green criteria, which includes "Recycling and Reuse", "Transportation", "Energy Efficiency and Conservation", "Water Efficiency and Conservation", "Commitment to Environmental Practices" and "Green Management". Each criterion is further defined by means of various indicators based on which the following questionnaires have been designed. The answer to the question in the survey is defined based on 5-point Likert scale and the scale is defined based on the linguistic variable as shown in the table below. Please select any one of the scale based on the linguistic variable that best suits your hotel. We assure that the data is collected only for the sole purpose of research study and the company name will remain confidential in any publication associated with this research work.

\begin{tabular}{cccccc}
\hline $\begin{array}{c}\text { Linguistic } \\
\text { variable }\end{array}$ & $\begin{array}{c}\text { Not implemented } \\
\text { at all (VP) }\end{array}$ & $\begin{array}{c}\text { Implemented to } \\
\text { some extent (P) }\end{array}$ & $\begin{array}{c}\text { Medium level of } \\
\text { implementation } \\
(\mathrm{MG})\end{array}$ & $\begin{array}{c}\text { Good } \\
\text { implementation } \\
(\mathrm{G})\end{array}$ & $\begin{array}{c}\text { Very good } \\
\text { implementation } \\
(\mathrm{VG})\end{array}$ \\
\hline $\begin{array}{c}\text { 5-point Likert } \\
\text { Scale }\end{array}$ & 1 & 2 & 3 & 4 & 5 \\
\hline
\end{tabular}

- Criteria 1: Recycling and Reuse:

$\bigcirc \quad$ SC1: How well your hotel has implemented water recycling system and minimizing waste throughout the hotel (e.g., applying waste water treatment to be used for irrigation)?

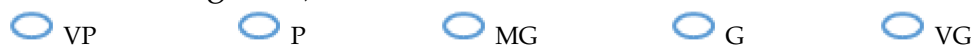

$\bigcirc \quad$ SC2: How your hotel implementing environmentally friendly raw materials likes returnable, reused, and recyclable packaging (e.g., recyclable containers for soap, etc)? 
SC3: How often your hotel is using the electronic files rather than paper ones?
$\bigcirc_{\mathrm{VP}}$
$\bigcirc_{\mathrm{P}}$
$\bigcirc_{M G}$
$\bigcirc_{\mathrm{G}}$
$\bigcirc_{V G}$

- Criteria 2: Transportation:

SC4: How good your hotel in Encouraging environmental friendly transportation through incentive. (e.g., Adding electrical charging station for guests with electric/hybrid cars or e-bike and e-scooter)?
$\bigcirc_{\mathrm{VP}}$
$\bigcirc_{p}$
$\bigcirc_{M G}$
$\bigcirc_{\mathrm{G}}$
$\bigcirc_{V G}$

SC5: How does your hotel Provide preferential car parking for alternative transport modes, such as electric, hybrid or biodiesel carpools?
$\bigcirc_{\mathrm{VP}}$
$\bigcirc_{P}$
$\bigcirc_{M G}$
$\bigcirc_{\mathrm{G}}$
$\bigcirc_{V G}$

SC6: How your hotel provides a secure location for staff to store and rent bicycles?
$\bigcirc_{\mathrm{VP}}$
$\bigcirc_{P} \quad \bigcirc_{M G}$
$\bigcirc_{G}$
$\bigcirc_{\text {VG }}$

\section{- Criteria 3: Energy Efficiency and Conservation}

SC7: How effective your hotel in Installing sensors or timers for the occupancy (motion) in low traffic areas (e.g., lights turn off automatically when the aisles are empty, etc)?
$\bigcirc_{\text {vP }}$
$\bigcirc_{\mathrm{p}}$
$\bigcirc_{M G}$
$\bigcirc_{G}$
$\bigcirc_{\mathrm{VG}}$

SC8: How good your hotel is using energy-efficient lamps, such as compact florescent (CFL) lights?
$\bigcirc_{\mathrm{VP}}$
$\mathrm{P}_{\mathrm{P}}$
$\bigcirc_{\text {MG }}$
$\bigcirc_{\mathrm{G}} \quad \bigcirc_{\mathrm{VG}}$

SC9: How well your hotel is using renewable sources of energy such as wind, solar, and geothermal resource lights (e.g., installing lights that work by solar energy, etc)?
$\mathrm{O}_{\mathrm{VP}}$
$\bigcirc_{\mathrm{P}}$
$\bigcirc_{\text {MG }}$
$\bigcirc_{\mathrm{G}}$
$\bigcirc_{\mathrm{VG}}$

SC10: How well your hotel in setting programmable thermostat in place (e.g., the air conditioner work according to the temperature of the room, etc.)?
$\bigcirc_{\mathrm{vP}}$
$\bigcirc_{P}$
$\bigcirc_{M G}$
$\bigcirc_{G}$
$\bigcirc_{\text {VG }}$

SC11: How well your hotel is using (key-card) to activate and turn off the electricity in rooms?
$\bigcirc_{\mathrm{VP}}$
$\bigcirc_{\mathrm{p}}$
$\bigcirc_{\text {MG }}$
$\bigcirc_{G}$
$\bigcirc$ VG

SC12: How well your hotel in Installing heat insulated windows or use natural sunlight to reduce the average energy usage?
$\bigcirc_{V P}$
$\bigcirc_{p}$
$\bigcirc_{\text {MG }}$
$\bigcirc_{\mathrm{G}}$
$\bigcirc_{\text {VG }}$

SC13: How well your hotel in using solar panels for heating waters?
$\bigcirc_{\mathrm{VP}}$
$\mathrm{P}_{\mathrm{P}}$
$\bigcirc_{\text {MG }}$
$\bigcirc_{\mathrm{G}}$
$\bigcirc \mathrm{VG}$

SC14: How well your hotel in making a reminding cards for visitors and workers to turn off the lights when they leave the room?
$\bigcirc_{\text {vP }}$
$\bigcirc_{P}$
$\bigcirc_{M G}$
$\bigcirc_{\mathrm{G}}$
$\bigcirc_{\text {VG }}$

SC15: How well your hotel in doing periodic maintenance for electrical devices (e.g., A/C, heaters, etc)?
$\bigcirc_{\mathrm{VP}}$
$\mathrm{P}_{\mathrm{P}}$
$\bigcirc_{M G}$
$\bigcirc_{G}$
$\bigcirc_{V G}$

- Criteria 4: Water Efficiency and Conservation:

SC16: How well your hotel in posting signs for promoting water in toilets, restaurants, and kitchen areas Preservation?
$\bigcirc_{\mathrm{VP}}$
$\bigcirc_{P}$
$\bigcirc_{\text {MG }}$
$\bigcirc_{\mathrm{G}}$
$\bigcirc_{\text {vG }}$

SC17: How well your hotel in checking for leaks and repairs periodically?
$\bigcirc_{\mathrm{VP}}$
$\bigcirc_{p}$
$\bigcirc_{M G}$
$\bigcirc_{\mathrm{G}}$
VG 
SC18: How well your hotel plan for washing machines, dryers, and dishwasher to be filled with recommend capacity each loop. (e.g., run full loads rather than running many small loads of laundry, etc.)?
$\bigcirc_{\text {VP }}$
$\bigcirc_{P}$
$O_{M G}$
$\bigcirc_{\mathrm{G}}$
VG

SC19: How well your hotel in using automatic irrigation system for garden (e.g., drip irrigation system)?
$\bigcirc_{\text {VP }}$
$\bigcirc_{P}$
MG
$\bigcirc_{\mathrm{G}}$
VG

SC20: How well your hotel is conserving water by using tabs sensors?

$\bigcirc_{\mathrm{VP}} \bigcirc_{\mathrm{P}} \quad \bigcirc_{\mathrm{MG}} \quad \bigcirc_{\mathrm{G}} \quad \bigcirc_{\mathrm{VG}}$

\section{Criteria 5: Commitment to Environmental Practices:}

SC21: How effective your hotel in providing an Environmental Committee that is responsible for creating a green environmental plan for the use of energy, water, and solid waste (e.g., regular meetings for employees to identify practices of green strategy)?
$\bigcirc_{\text {VP }}$
$\bigcirc_{P}$
$\bigcirc_{M G}$
$\bigcirc_{\mathrm{G}}$
$\bigcirc_{\text {VG }}$

SC22: How well your hotel staff are informing for any issues related to environment (e.g., smoking in forbidden places)?
$\bigcirc_{\text {vP }}$
${ }_{P}$
$\bigcirc_{\text {MG }}$
$\bigcirc_{G}$
$\bigcirc_{\text {VG }}$

$\bigcirc \quad$ SC23: How often your hotel making an effort in communicating with the guests, personnel, Shareholders, salespeople, and the public regarding environmental issues (e.g., providing environmental tips for the guest, etc.)?
$\bigcirc_{\mathrm{VP}}$
$\mathrm{P}_{\mathrm{P}}$
$\bigcirc_{M G}$
$\bigcirc_{G}$
$\bigcirc_{V G}$

- Criteria 6: Green Management:

SC24: How well your hotel in offering training to the employees on issues relating to the protection of environment?
$\bigcirc_{\text {VP }}$
$\mathrm{OP}_{\mathrm{P}}$
$\bigcirc_{M G}$
$\bigcirc_{\mathrm{G}}$
$\bigcirc_{\text {VG }}$

SC25: How well your hotel has implemented incentives to the staff in case of submitting suggestions for environmental issues?
$\bigcirc_{\text {VP }}$
$\mathrm{OP}_{\mathrm{P}}$
$\bigcirc_{\text {MG }}$
$\bigcirc_{\mathrm{G}}$
$\bigcirc_{\text {VG }}$

SC26: How well your hotel is identifying of waste in such a way that appropriate control strategy can be made (e.g., provide containers for recyclable items)?

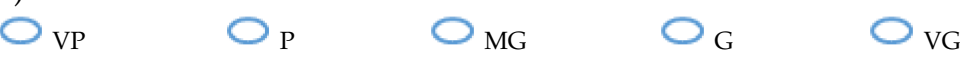

\section{References}

1. Merli, R.; Preziosi, M.; Acampora, A.; Ali, F. Why should hotels go green? Insights from guests experience in green hotels. Int. J. Hosp. Manag. 2019, 81, 169-179. [CrossRef]

2. Agag, G.; Colmekcioglu, N. Understanding guests' behavior to visit green hotels: The role of ethical ideology and religiosity. Int. J. Hosp. Manag. 2020, 91, 102679. [CrossRef]

3. Asadi, S.; Pourhashemi, S.O.; Nilashi, M.; Abdullah, R.; Samad, S.; Yadegaridehkordi, E.; Razali, N.S. Investigating Influence of Green Innovation on Sustainability Performance: A Case on Malaysian Hotel Industry. J. Clean. Prod. 2020, 258, 120860. [CrossRef]

4. Al-Aomar, R.; Hussain, M. An assessment of green practices in a hotel supply chain: A study of UAE hotels. J. Hosp. Tour. Manag. 2017, 32, 71-81. [CrossRef]

5. Ahmed, M.; Guo, Q.; Qureshi, M.A.; Raza, S.A.; Khan, K.A.; Salam, J. Do green HR practices enhance green motivation and proactive environmental management maturity in hotel industry? Int. J. Hosp. Manag. 2021, 94, 102852. [CrossRef]

6. Manzoor, F.; Wei, L.; Asif, M. The contribution of sustainable tourism to economic growth and employment in Pakistan. Int. J. Environ. Res. Public Health 2019, 16, 3785. [CrossRef]

7. Rebollo, J.F.V.; Baidal, J.A.I. Measuring sustainability in a mass tourist destination: Pressures, perceptions and policy responses in Torrevieja, Spain. J. Sustain. Tour. 2003, 11, 181-203. [CrossRef]

8. Reid, S.; Johnston, N.; Patiar, A. Coastal resorts setting the pace: An evaluation of sustainable hotel practices. J. Hosp. Tour. Manag. 2017, 33, 11-22. [CrossRef] 
9. Pan, S.Y.; Gao, M.; Kim, H.; Shah, K.J.; Pei, S.L.; Chiang, P.C. Advances and challenges in sustainable tourism toward a green economy. Sci. Total Environ. 2018, 635, 452-469. [CrossRef]

10. Manaktola, K.; Jauhari, V. Exploring consumer attitude and behaviour towards green practices in the lodging industry in India. Int. J. Contemp. Hosp. Manag. 2007, 19, 364-377. [CrossRef]

11. Dief, M.E.; Font, X. The determinants of hotels' marketing managers' green marketing behaviour. J. Sustain. Tour. 2010, 18, 157-174. [CrossRef]

12. Kim, J.Y.; Hlee, S.; Joun, Y. Green practices of the hotel industry: Analysis through the windows of smart tourism system. Int. J. Inf. Manag. 2016, 36, 1340-1349. [CrossRef]

13. Lin, C.Y.; Ho, Y.H. Determinants of green practice adoption for logistics companies in China. J. Bus. Ethics 2011, 98, 67-83. [CrossRef]

14. Masri, H.A.; Jaaron, A.A. Assessing green human resources management practices in Palestinian manufacturing context: An empirical study. J. Clean. Prod. 2017, 143, 474-489. [CrossRef]

15. Mensah, I. Environmental management practices among hotels in the greater Accra region. Int. J. Hosp. Manag. 2006, $25,414-431$. [CrossRef]

16. Bohdanowicz, P. Environmental awareness and initiatives in the Swedish and Polish hotel industries-Survey results. Int. J. Hosp. Manag. 2006, 25, 662-682. [CrossRef]

17. Lee, C.H.; Wahid, N.A.; Goh, Y.N. Assessing determinants of green practices adoption: A conceptual framework. Elixir Mark. Manag. 2012, 45, 7760-7766.

18. Horovitz. Can Restaurants Go Green, Earn Green? 2008. Available online: https://drive.google.com/file/d/1hh0pqME2-8 8CqNr4MWxz6XHPDiFoD3sz/view? usp=sharing (accessed on 12 August 2015).

19. $\mathrm{Wu}, \mathrm{Y}$; $\mathrm{Xu}, \mathrm{C} . ; \mathrm{Zhang}$, T. Evaluation of renewable power sources using a fuzzy MCDM based on cumulative prospect theory: A case in China. Energy 2018, 147, 1227-1239. [CrossRef]

20. Rabetino, R.; Kohtamäki, M.; Fedarico, J. A (Re)view of the Philosophical Foundations of Strategic Management. Int. J. Manag. Rev. 2021, 23, 151-190. [CrossRef]

21. Singjai, K.; Winata, L.; Kummer, T.F. Green initiatives and their competitive advantage for the hotel industry in developing countries. Int. J. Hosp. Manag. 2018, 75, 131-143. [CrossRef]

22. Yusoff, Y.M.; Nejati, M.; Kee, D.M.H.; Amran, A. Linking Green Human Resource Management Practices to Environmental Performance in Hotel Industry. Glob. Bus. Rev. 2020, 21, 663-680. [CrossRef]

23. Shah, K.J.; Pan, S.-Y.; Lee, I.; Kim, H.; You, Z.; Zheng, J.-M.; Chiang, P.-C. Green transportation for sustainability: Review of current barriers, strategies, and innovative technologies. J. Clean. Prod. 2021, 326, 129392. [CrossRef]

24. Erdogan, N.; Baris, E. Environmental protection programs and conservation practices of hotels in Ankara, Turkey. Tour. Manag. 2007, 28, 604-614. [CrossRef]

25. Omidiani, A.; HashemiHezaveh, S. Waste Management in Hotel Industry in India: A Review. Int. J. Sci. Res. Publ. 2016, 6, 670-680.

26. Beullens, P.; Ghiami, Y. Waste reduction in the supply chain of a deteriorating food item-Impact of supply structure on retailer performance. Eur. J. Oper. Res. 2021. [CrossRef]

27. Sencer, S. Is It More Important to You to Reduce, Reuse or Recycle? KQED 2016. Available online: www.kqed.org/education/31 8579 /is-it-more-important-to-you-to-reduce-reuse-or-recycle (accessed on 28 October 2016).

28. Triki, C.; Piya, S.; Fu, L.L. Integrating production scheduling and transportation procurement through combinatorial auctions. Networks 2020, 76, 147-163. [CrossRef]

29. Rinkesh, R.; Modes and Benefits of Green Transportation. Conserve Energy Future 2017. Available online: www.conserve-energyfuture.com/modes-and-benefits-of-green-transportation.php (accessed on 15 January 2017).

30. Sardianou, E.; Kostakis, I.E. Perceived barriers to invest in renewable energy sources in the Cretan hotel industry. Int. J. Sustain. Energy 2020, 39, 240-249. [CrossRef]

31. López-Bernabé, E.; Foudi, S.; Linares, P.; Galarraga, I. Factors affecting energy-efficiency investment in the hotel industry: Survey results from Spain. Energy Effic. 2021, 14, 41. [CrossRef] [PubMed]

32. Han, H.; Lee, J.-S.; Trang, H.L.T.; Kim, W. Water conservation and waste reduction management for increasing guest loyalty and green hotel practices. Int. J. Hosp. Manag. 2018, 75, 58-66. [CrossRef]

33. Aivazidou, E.; Tsolakis, N.; Vlachos, D.; Iakovou, E. A water footprint management framework for supply chains under green market behaviour. J. Clean. Prod. 2018, 197, 592-606. [CrossRef]

34. El-Kassar, A.N.; Singh, S.K. Green innovation and organizational performance: The influence of big data and the moderating role of management commitment and HR practices. Technol. Forecast. Soc. Chang. 2019, 144, 483-498. [CrossRef]

35. Azizuddin, M.; Shamsuzzuha, A.; Piya, S. Influence of Circular Economy Phenomenon to Fulfil Global Sustainable Development Goals: Perspective from Bangladesh. Sustainability 2021, 13, 1455. [CrossRef]

36. Zaid, A.A.; Jaaron, A.A.; Bon, A.T. The impact of green human resource management and green supply chain management practices on sustainable performance: An empirical study. J. Clean. Prod. 2018, 204, 965-979. [CrossRef]

37. Islam, M.A.; Jantan, A.H.; Yusoff, Y.M.; Chong, C.W.; Hossain, M.S. Green Human Resource Management (GHRM) Practices and Millennial Employees' Turnover, Intentions in Tourism Industry in Malaysia: Moderating Role of Work Environment. Glob. Bus. Rev. 2020, 0972150920907000. [CrossRef] 
38. Sari, K.; Suslu, M. A modeling approach for evaluating green performance of a hotel supply chain. Technol. Forecast. Soc. Chang. 2018, 137, 53-60. [CrossRef]

39. Piya, S.; Shamsuzzoha, A.; Khadem, M.; Al Kindi, M. Integrated analytical hierarchy process and grey relational analysis approach to measure supply chain complexity. Benchmarking Int. J. 2021, 28, 1273-1295. [CrossRef]

40. Wang, Y.M.; Chin, K.S. Fuzzy analytic hierarchy process: A logarithmic fuzzy preference programming methodology. Int. J. Approx. Reason. 2011, 52, 541-553. [CrossRef]

41. Kabir, G.; Hasin, M.A.A. Comparative analysis of AHP and fuzzy AHP models for multicriteria inventory classification. Int. J. Fuzzy Log. Syst. 2011, 1, 1-16.

42. Shamsuzzoha, A.; Piya, S.; Shamsuzzaman, M. Application of fuzzy TOPSIS framework for selecting complex project in a case company. J. Glob. Oper. Strateg. Sourc. 2021, 14, 528-566. [CrossRef]

43. Saaty, T.L. How to make a decision: The analytic hierarchy process. Eur. J. Oper. Res. 1990, 48, 9-26. [CrossRef]

44. Arunachalam, R.; Piya, S.; Krishnan, P.K.; Muraliraja, R.; Christy, J.V.; Mourad AH, I.; Al-Maharbi, M. Optimization of stir-squeeze casting parameters for production of metal matrix composites using a hybrid analytical hierarchy process-Taguchi-Grey approach. Eng. Optim. 2020, 52, 1166-1183. [CrossRef]

45. Bhosale, V.A.; Kant, R. An integrated ISM fuzzy MICMAC approach for modelling the supply chain knowledge flow enablers. Int. J. Prod. Res. 2016, 54, 7374-7399. [CrossRef]

46. Yap, J.Y.; Ho, C.C.; Ting, C.Y. Analytic Hierarchy Process (AHP) for business site selection. In Proceedings of the 6th International Conference on Computer Science and Computational Mathematics, AIP Publishing LLC, Langkawi, Malaysia, 4-5 May 2018.

47. Torfi, F.; Farahani, R.Z.; Rezapour, S. Fuzzy AHP to determine the relative weights of evaluation criteria and Fuzzy TOPSIS to rank the alternatives. Appl. Soft Comput. 2010, 10, 520-528. [CrossRef]

48. Khanna, R.; Kumar, A.; Garg, M.P.; Singh, A.; Sharma, N. Multiple performance characteristics optimization for Al 7075 on electric discharge drilling by Taguchi grey relational theory. J. Ind. Eng. Int. 2015, 11, 459-472. [CrossRef]

49. Kore, M.N.B.; Ravi, K.; Patil, A.P.M.S. A simplified description of fuzzy TOPSIS method for multi criteria decision making. Int. Res. J. Eng. Technol. 2017, 4, 2047-2050.

50. Wang Chen, H.M.; Chou, S.Y.; Luu, Q.D.; Yu, T.H.K. A fuzzy MCDM approach for green supplier selection from the economic and environmental aspects. Math. Probl. Eng. 2016, 2016, 8097386. [CrossRef]

51. Shirouyehzad, H.; Dabestani, R. Evaluating Projects Based on Safety Criteria; Using TOPSIS. In Proceedings of the 2011 2nd International Conference on Construction and Project Management IPEDR, Singapore, 16-18 September, 2011; Volume 15, pp. 69-73.

52. Piya, S.; Shamsuzzoha, A.; Khadem, M.; Al-Hinai, N. Identification of critical factors and their interrelationships to design agile supply chain: Special focus to oil and gas industries. Glob. J. Flex. Syst. Manag. 2020, 21, 263-281. [CrossRef]

53. Fernandes, C.I.; Veiga, P.M.; Ferreira, J.J.; Hughes, M. Green growth versus economic growth: Do sustainable technology transfer and innovations lead to an imperfect choice? Bus. Strategy Environ. 2021, 30, 2021-2037. [CrossRef] 